The results of the trial show us that the participants have a good physical condition as they do a series of physical exercises on a daily basis according to the study curriculum. These results are similar to the ones in the specialty literature where the pyramid of physical activities plays an important role. The young adults, respectively the students, are very active from a physical point of view and therefore can be found on the first 3 levels of the pyramid, according to a healthy lifestyle that they should continue as much as possible.

References
1. Bouchard C, Blair SN, Haskell WL. Physical activity and health. Human Kinetics, Champaign; 2007.

2. American College of Sports Medicine. ACSM'S Guidelines for Exercices Testing and Prescription (GETP). 8th ed. Philadelphia: Lippincott Williams and Wilkins; 2010.

3. Paffenbarger RS Jr1, Blair SN, Lee IM. A history of physical activity, cardiovascular health and longevity: the scientific contributions of Jeremy N Morris, DSc, DPH, FRCP, Int. J Epidemiol. 2001 Oct; 30(5): 1184-92.

4. Hoeger Werner WK, Hoeger Sharon A. Fitness and Wellness. 9th ed. Wadsworth: Cengage Learning; 2011.

5. Howley Edward T, Thompson Dixie L. Fitness professional's handbook. 6th ed. Human Kinetics, Champaign; 2012.

6. American College of Sports Medicine. ACSM's Health-Related Physical Fitness Assessment Manual (HRPFAM). 3rd ed. Philadelphia: Lippincott Williams and Wilkins; 2010.

7. Plowman Sharon A, Smith Denise L. Exercise physiology for health, fitness and performance. 3rd ed. Philadelphia: Lippincott Williams and Wilkins; 2011.

8. Corbin BC, Welk JG, Corbin RW, Welk AK. Concept of physical fitness. Active Lifestyles for Wellness. New York: McGraw-Hill; 2008.

9. American College of Sports Medicine. ACSM's Resource Manual for Guidelines for Exercises Testing and Prescription (RMGETP). 6th ed. Philadelphia: Lippincott Williams and Wilkins; 2010.

10. Garber CE, Blissmer B, Deschenes MR, Franklin BA, Lamonte MJ, Lee IM, et al. American College of Sports Medicine position stand: quantity and quality of exercise for developing and maintaining cardiorespiratory, musculoskeletal, and neuromotor fitness in apparently healthy adults: guidance for prescribing exercise. Medicine and Science in Sports and Exercise. 2011; 43 (7): 1334-59.

Цитування на цю статтю:

Sinziana Calina Silisteanu, Andrei Emanuel Silisteanu. The importance for young adults to do physical activities for a healthy lifestyle. Вісник Прикарпатського університету. Серія: Фізична культура. 2019 Берез 26; 33 : 84-89

\begin{tabular}{|c|c|}
\hline Відомості про автора: & Information about the author: \\
\hline $\begin{array}{l}\text { Сінціана Каліна Силістеану - Сучавський уні- } \\
\text { верситет імені Штефан чел Маре (Сучава, Румунія) }\end{array}$ & $\begin{array}{l}\text { Sinziana Calina Silisteanu - "Stefan cel Mare" } \\
\text { University of Suceava (Suceava, Romania) }\end{array}$ \\
\hline \multicolumn{2}{|l|}{ e-mail:sinzi_silisteanu @yahoo.com } \\
\hline $\begin{array}{l}\text { Анорій Eмануель Силістеану - } \text { Університет } \\
\text { Бабеш-Боляі (Клуж-Напока, Румунія) }\end{array}$ & $\begin{array}{l}\text { Andrei Emanuel Silisteanu - Babeş-Bolyai University } \\
\text { (Cluj-Napoca, Romania) }\end{array}$ \\
\hline
\end{tabular}

УДК 796.2; 612.17 “15/17”

doi: 10.15330/fcult.33.89-96

Андрій Соломонко, Андрій Андрес

\title{
СИСТЕМАТИЗАЦІЯ РУХЛИВИХ ІГОР ТА РОЗВАГ ДЛЯ СТУДЕНТІВ 15-17 РОКІВ ЗГІДНО ЇХ ПУЛЬСОВОЇ ВАРТОСТІ
}

В статті поданий детальний аналіз досвіду застосування рухливих ігор як засобу педагогічного впливу та засобу психофізичного розвитку особистості. Проаналізована можливість застосування ігор серед контингенту студентів коледжів як з педагогічно-виховною метою $і$ як фактору впливу на організм людини. Підібрані та складені в окремі блоки комплекси рухливих ігор різного педагогічнорозвиваючого характеру. Здійснений збір показників частоти сериевих скорочень студентів I-II курсів, 15-17 річного віку під час застосування ігор та розваг в рамках експериментальної програми. Детально описана та наведена класифікація ігор за рівнем впливу їх на серцеву судинну систему студентів. Проаналізована можливість застосування та дозування ігор з метою розвитку певних фізичних якостей опираючись на отримані данні. 
Ключові слова: студенти, рухливі ігри та розваги, пульсометрія, серцево-судинна система, фiзична підготовленість, рухові якості.

The article gives a detailed analysis of the experience of using games and entertainment as a means of pedagogical influence and means of psychophysical development of personality. Analyze the possibility of using games among the contingent of college students in pedagogical and educational purposes and as a factor in influencing the human body. Selected and composed in separate blocks of complexes of games and entertainment of various pedagogically-developing character. The cardiovascular rates of I-II year students aged 15-17 at the time of the use of games and entertainments within the framework of the experimental program were collected. The classification of games is described in detail and the degree of their impact on the cardiovascular system of the students. The possibility of application and dosage of games for the development of certain physical qualities based on the obtained data is analyzed.

Key words: Students, basic directions, pulse measurement, the cardiovascular system, physical condition, motor skills.

\section{Постановка проблеми.}

Дані багаточисельних досліджень дозволили виявити, що за останні роки суттєво зросла кількість серцево-судинних захворювань, і не тільки у осіб середнього, старшого віку, але і серед підлітків. Серед факторів ризику розвитку коронарного атеросклерозу у молодому віці нераціональне харчування, паління, вживання алкоголю (А. Соломонко, 2012). не останнє місце посідає малорухомий спосіб життя, Гра - одна з основних форм діяльності людини. Характерною особливістю гри є тісний іiї зв'язок із суспільним життям, але в грі важливий лише певний ступінь свободи у прийнятті рішень, виборі засобів реалізації в практичній реалізації певних ігрових дій (С.Н. Приступа 2012).

Гра є вагомим емоційно-мотиваційним чинником самовдосконалення, оскільки в легкій і невимушеній формі спонукає людину до розвитку. Значення вправ, ігор і розваг зростає завдяки можливості їх широкого застосування в природних умовах. Використання ігор в поєднанні з іншими засобами забезпечує високу ефективність виховання позитивних рис характеру [1].

Корисний ефект фізичні вправи та ігри дадуть тільки під впливом систематичного їх застосування, що призведе до структурних змін в обміні речовин і механізмах, які керують діяльністю організму та ведуть до покращення функціональних можливостей серцево-судинної, дихальної та інших систем. Підвищення економізації їх діяльності сприяє покращенню резервних можливостей організму, однак, для цього необхідно щоб методика проведення занять фізичними вправами, іграми та розвагами базувалась на сучасних наукових, педагогічних та медико-біологічних принципах. Тільки в такому випадку заняття фізичними вправами та іграми стануть стимулом в бажанні зміцнювати здоров’я і попереджатимуть можливе виникнення захворювань.

Як процес людської діяльності гра давно вивчається вченими багатьох галузей наук: педагогіка, психологія, фізична культура і спорт. Вчені одностайно прийшли до висновку, що гра - школа думки, почуттів і волі. В іграх не тільки виявляються, а й формуються всі психічні процеси та властивості дітей, їх спостережливість, уважність, вдумливість, наполегливість, сміливість, рішучість, уміння, навички, здібності [3].

В процесі реалізації ігрових форм, відбувається залучення всіх студентів до активної співпраці (під час розв'язання ігрових завдань). Таким чином може здійснюватись колективне, групове, індивідуальне та в парах - навчання у співпраці (студенти i викладач є активним “суб'єктом” процесу навчання. При цьому, виникає ситуація коли колектив практично навчає і виховує кожну окрему особистість (В.Дяченко, 2001)).

Незважаючи на те, що автори (В.О Кучер 2013, С.Н. Приступа 2012, А.П Демчишин 1984, А.В. Цьось 2000 та ін.) в достатній мірі обгрунтовували застосування ігор для покращення фізичного розвитку, в переважній більшості це стосувалось аудиторних занять. На нашу думку, сьогодні особливо актуальною $є$ потреба в розробці методології застосування ігор та розваг в процесі позааудитрних занять в інтеграції даного 
методу в проведення спортивних свят, туристичних, культурно-просвітнитських, оздоровчих та виховних заходів, що підвищить мотивацію до самовдосконалення.

Також сьогодні наука володіє засобами моніторингу та наявними результатами вивчення показників частоти серцевих скорочень (ЧСС) на організм студентів, детально описаний аналіз фізіологічних кривих, надані рекомендації з планування щільності заняття спираючись на ці данні (А.В. Магльований 2015). При тому відсутня така важлива інформація, як вплив на серцево-судинну систему (ССC) фізичного навантаження спричиненого певними рухливими іграми, максимальних та середніх показників ЧСС, що не дозволяє в повній мірі адекватно дозувати навантеження для певної вікової категорії використовуючи ігровий метод.

Мета дослідження - систематизувати рухливі ігри згідно їх впливу на серцевосудинну систему студентів коледжів.

\section{Завдання:}

1. З’ясувати педагогічні та медико-біологічні особливості проведення рухливих ігор з віковою групою, що вивчається за даними літературних джерел.

2. Скласти класифікацію рухливих ігор за рівнем їх впливу на серцево-судинну систему студентів.

\section{Методи й організація дослідження.}

Методи:

1. Аналіз літературних джерел.

2. Педагогічне спостереження.

3. Пульсометрія.

Експеримент тривав протягом дев'яти місяців 2017-2018 навчального року, в ньому брало участь 40 осіб, студенти I-II курсу, віком 15-17 років, Львівського кооперативного коледжу економіки і права (ЛККЕіП). В процесі дослідження нами було підібрано та виділено в окремі блоки перелік рухливих ігор: для розвитку рухових якостей, ігри різного педагогічно-розвиваючого характеру, а також ігри 3 різною кількістю учасників. Детальний опис застосованих ігор в процесі експерименту представлений в методичному посібнику “Вправи, ігри та розваги у вільний час" [2]. Зміст даних ігор містив змагальну складову. Ігри добирались за принципом підтримки високого емоційного рівня та зацікавленості в процесі проведення. Дані ігри ми застосовували в процесі позаурочних заходів. Згідно з умовою дослідження учасники протягом навчального року відвідували позааудиторні заходи, відповідно до плану виховної роботи навчального закладу (туристичні походи, спортивні свята тощо), під час яких застосовувався комплекс рухливих ігор та розваг, заходи відбувались один раз на два тижні.

3 метою визначення ступеню впливу на ССС студентів ми використали систему пульсометрії Polar, а саме нагрудні датчики Н10. За результатами експерименту нами були складені таблиці із класифікацією ігор згідно їх впливу на ССС студентів. В процесі експерименту було застосовано 46 ігор та визначено їх пульсову вартість, визначався максимальний та середній показник ЧСС під час гри.

Ігри за рівнем інтенсивності були поділені на 5 груп, так як це пропонує виробник приладів (пульсометрів) і відповідно налаштоване програмне забезпечення. За максимальний показник ЧСС вважається показник 220 мінус вік того хто досліджується, від того показника у відсотковому значенні розраховуються зони інтенсивності тренувань, Класична формула Хаскеля-Фокса. Дана формула має багато недоліків, оскільки не враховує індивідуальні особливості та ефекту тренованості, хоча і бере до уваги довжину та масу тіла досліджуваних. Тому для побудови процесу тренувань вимагає індивідуальних налаштувань діапазонів ЧСС, корегування в залежності від змін показників, швидкості відновлення тощо. Спеціалісти одностайні в тому, що точні результати можуть дати лише експериментальні тести (стрес-тести або навантажувальні тести), що визначають максимальний пульс та споживаний об’єм кисню кожної 
конкретної людини. Всі теоретичні методи будуть в тій чи іншій мірі неточні, все залежить від стану здоров'я та фізичної форми спортсмена.

Але відповідно до мети нашого дослідження даний спосіб розподілу зон інтенсивності є цілком прийнятним та безпечним для здоров'я студентів. Отже, контингент, що ми досліджували студенти I курсу 16 річні юнаки та дівчата.

Відповідно:

І група - дуже низької інтенсивності - ЧСС в діапазоні 102-122 ударів за хвилину. Тренування в тому діапазоні має вкрай низьку інтенсивність.

II група - низької інтенсивності - ЧСС 122-143 уд/хв. Тренування призначені для підвищення витривалості і є невід'ємною частиною будь-якої програми тренувань.

III група - середньої інтенсивності - ЧСС 143-163 уд/хв. У цьому діапазоні інтенсивність тренування вища, ніж в діапазонах I і II, однак вона продовжує залишатися аеробного характеру. Тренування в діапазоні 3 може складатися з декількох інтервалів, що чергуються з періодами відновлення.

IV група - інтенсивне тренування - ЧСС 163-184 уд/хв здійснюється анаеробне тренування в інтервалах до 10 хвилин. Чим коротше інтервал, тим вище інтенсивність.

V група - максимальна інтенсивність ЧСС 184-204 уд/хв. Анаеробне навантаження, наближене до максимального.

Важливо, щоб між інтервалами тренування в цих діапазонах IV i V було достатньо часу на відновлення. Структура тренування в діапазонах призначена для досягнення максимальних показників.

\section{Результати і дискусія.}

Нижче представленні показники ЧСС зафіксовані під час проведення частини ігор, що застосовувались в дослідженні. Темнішими комірками позначені діапазони в яких було зафіксований максимальний (піковий) показник, сірий колір позначає діапазон середнього значення пульсу підчас виконання гри.

В таблицях 1-6 поданий перелік ігор, які використовувались під час дослідження для розвитку рухових якостей та подана їх пульсова вартість.

Таблиия 1

Середні показники пульсової вартості ігор для розвитку сили

\begin{tabular}{|c|c|c|c|c|c|c|}
\hline \multirow{2}{*}{$\begin{array}{l}\text { № } \\
\text { 3/II }\end{array}$} & \multirow{2}{*}{$\begin{array}{c}\text { Назва вправ, ігор, } \\
\text { розваг }\end{array}$} & \multicolumn{5}{|c|}{ Рівні інтенсивності за ЧСС, уд/хв } \\
\hline & & $\begin{array}{c}\text { Дуже } \\
\text { низький } \\
(102-122)\end{array}$ & $\begin{array}{l}\text { Низький } \\
\text { (122-143) }\end{array}$ & $\begin{array}{l}\text { Середній } \\
(143-163)\end{array}$ & $\begin{array}{l}\text { Інтенсив. } \\
(163-184)\end{array}$ & $\begin{array}{c}\text { Макс. } \\
(184-204)\end{array}$ \\
\hline 1 & $\begin{array}{c}\text { Перетягування - } \\
\text { виштовхування }\end{array}$ & & & & & \\
\hline 2 & Звільнення полонених & & & & & \\
\hline 3 & Втримайся навпочіпки & & & & & \\
\hline 4 & Бій півнів & & & & & \\
\hline 5 & Перетягування пар & & & & & \\
\hline 6 & $\begin{array}{c}\text { Ходіння в упорі на руках } \\
\text { в трійках }\end{array}$ & & & & & \\
\hline 7 & $\begin{array}{l}\text { Переноска партнерів в } \\
\text { колоні }\end{array}$ & & & & & \\
\hline 8 & $\begin{array}{c}\text { Переноска в партнерів } \\
\text { шеренгах }\end{array}$ & & & & & \\
\hline
\end{tabular}


Середні показники пульсової вартості ігор для розвитку спритності

Таблиия 2

\begin{tabular}{|c|c|c|c|c|c|c|}
\hline \multirow{2}{*}{$\begin{array}{c}\text { № } \\
\text { 3/п }\end{array}$} & \multirow{2}{*}{$\begin{array}{c}\text { Назва вправ, ігор, } \\
\text { розваг }\end{array}$} & \multicolumn{5}{|c|}{ Рівні інтенсивності за ЧСС } \\
\cline { 3 - 7 } & & $\begin{array}{c}\text { Дуже } \\
\text { низький } \\
(102-122)\end{array}$ & $\begin{array}{c}\text { Низький } \\
(122-143)\end{array}$ & $\begin{array}{c}\text { Середній } \\
(143-163)\end{array}$ & $\begin{array}{c}\text { Інтенсив. } \\
(163-184)\end{array}$ & $\begin{array}{c}\text { Макс. } \\
(184-204)\end{array}$ \\
\hline 1 & $\begin{array}{c}\text { Передача м'яча } \\
\text { змійкою }\end{array}$ & & & & & \\
\hline 2 & Гонки мішені & & & & \\
\hline 3 & Вершники з м'ячем & & & & \\
\hline 4 & Перетягування пар & & & & \\
\hline 5 & Стрибаюча колона & & & & \\
\hline 6 & Квач & & & & \\
\hline
\end{tabular}

Табличя 3

Середні показники пульсової вартості ігор для розвитку витривалості

\begin{tabular}{|c|c|c|c|c|c|c|}
\hline \multirow{2}{*}{$\begin{array}{c}\text { № } \\
\text { 3/п }\end{array}$} & \multirow{2}{*}{$\begin{array}{c}\text { Назва вправ, ігор, } \\
\text { розваг }\end{array}$} & \multicolumn{5}{|c|}{ Рівні інтенсивності за ЧСС } \\
\cline { 3 - 7 } & & $\begin{array}{c}\text { Дуже } \\
\text { низький } \\
(102-122)\end{array}$ & $\begin{array}{c}\text { Низький } \\
(122-143)\end{array}$ & $\begin{array}{c}\text { Середній } \\
(143-163)\end{array}$ & $\begin{array}{c}\text { Інтенсив. } \\
(163-184)\end{array}$ & $\begin{array}{c}\text { Макс. } \\
(184-204)\end{array}$ \\
\hline 1 & Міні-волейбол & & & & & \\
\hline 2 & Біг в обручі & & & & & \\
\hline 3 & Командна сутичка & & & & & \\
\hline 4 & Пересувні ворота & & & & & \\
\hline 5 & Квадрат & & & & & \\
\hline
\end{tabular}

Табличя 4

Середні показники пульсової вартості ігор для розвитку гнучкості

\begin{tabular}{|c|c|c|c|c|c|c|}
\hline \multirow{2}{*}{$\begin{array}{c}\text { № } \\
\text { 3/п }\end{array}$} & \multirow{2}{*}{$\begin{array}{c}\text { Назва вправ, ігор, } \\
\text { розваг }\end{array}$} & \multicolumn{5}{|c|}{ Рівні інтенсивності за ЧСС } \\
\cline { 3 - 7 } & & $\begin{array}{c}\text { Дуже } \\
\text { низький } \\
\end{array}$ & $\begin{array}{c}\text { Низький } \\
(122-143)\end{array}$ & $\begin{array}{c}\text { Середній } \\
(143-163)\end{array}$ & $\begin{array}{c}\text { Інтенсив. } \\
(163-184)\end{array}$ & $\begin{array}{c}\text { Макс. } \\
(184-204)\end{array}$ \\
\hline 1 & Стопи на вколішках & & & & & \\
\hline 2 & Прогин в попереку & & & & & \\
\hline 3 & Штовхання ніг & & & & & \\
\hline
\end{tabular}

Середні показники пульсової вартості ігор для розвитку швидкості

Таблиия 5

\begin{tabular}{|c|c|c|c|c|c|c|}
\hline \multirow{2}{*}{$\begin{array}{c}\text { № } \\
\text { 3/п }\end{array}$} & \multirow{2}{*}{$\begin{array}{c}\text { Назва вправ, ігор, } \\
\text { розваг }\end{array}$} & \multicolumn{5}{|c|}{ Рівні інтенсивності за ЧСС } \\
\cline { 3 - 7 } & & $\begin{array}{c}\text { Дуже } \\
\text { низький } \\
\end{array}$ & $\begin{array}{c}\text { Низький } \\
(122-143)\end{array}$ & $\begin{array}{c}\text { Середній } \\
(143-163)\end{array}$ & $\begin{array}{c}\text { Iнтенсив. } \\
(163-184)\end{array}$ & $\begin{array}{c}\text { Макс. } \\
(184-204)\end{array}$ \\
\hline 1 & Оволодій м'ячем & & & & & \\
\hline 2 & Оволодій предметом & & & & & \\
\hline 3 & Хто швидше & & & & & \\
\hline 4 & Біг спиною вперед & & & & & \\
\hline
\end{tabular}


Середні показники пульсової вартості ігор для розвитку швидкісної сили

\begin{tabular}{|c|c|c|c|c|c|c|}
\hline \multirow{2}{*}{$\begin{array}{l}\text { № } \\
\text { 3/II }\end{array}$} & \multirow{2}{*}{$\begin{array}{c}\text { Назва вправ, ігор, } \\
\text { розваг }\end{array}$} & \multicolumn{5}{|c|}{ Зони рівнів інтенсивності за ЧСС } \\
\hline & & $\begin{array}{c}\text { Дуже } \\
\text { низький } \\
(102-122)\end{array}$ & $\begin{array}{c}\text { Низький } \\
\text { (122-143) }\end{array}$ & $\begin{array}{l}\text { Середній } \\
(143-163)\end{array}$ & $\begin{array}{l}\text { Інтенсив. } \\
(163-184)\end{array}$ & $\begin{array}{c}\text { Макс. } \\
(184-204)\end{array}$ \\
\hline 1 & Стрибаючий мисливець & & & & & \\
\hline 2 & Стрибаюча колона & & & & & \\
\hline
\end{tabular}

Як бачимо із результатів дослідження рухливі ігри спрямовані на розвиток певних рухових якостей, з даною віковою групою, проходять в різних діапазонах ЧСС. Зокрема, подані ігри для розвитку сили і спритності можуть проходити як в діапазоні низької інтенсивності, так і інтенсивного тренування. Розвиток витривалості: дуже низької і низької інтенсивності. Ігри для розвитку гнучкості та швидкості - низька та середня зони інтенсивності, а розвиток швидкісної сили відбувався в зоні середнього та інтенсивного тренування.

Обговорення: За мінімум рухової активності здорових людей прийнято рахувати три години занять на тиждень вправами, іграми та розвагами, при умові, що вони виконуються з 60\% інтенсивності від максимальної, при збереженні правильного режиму життя і харчування [2]. Під впливом притаманних грі змагань, значно активніше формується і розвивається рухова сфера організму (рухові якості), вдосконалюється сприйняття і швидкість реагування, розвивається здібність до аналізу і прийняття рішень, що позитивно відбивається на формуванні оперативного мислення і розумових процесів взагалі.

Отже запропонована нами класифікація ігор має на меті дати можливість фахівцям 3 фізичного виховання, що працюють 3 даною віковою групою, більш цілеспрямовано впливати на розвиток певних рухових якостей за допомогою рухливих ігор. Кожна із застосованих ігор може мати різну тривалість, відповідно до сценарію та розвитку подій. Тому дозування та навантаження залежить від тривалості гри і з яких необхідно складати блоки в залежності від мети конкретного заняття. Для більш раціонального використання ігор їх слід чергувати за ступенем впливу на ССС: ігри з високою або максимальною інтенсивністю 3 дуже низькою. При застосуванні ігор, що тривають довший час, при дозуванні, слід відштовхуватись від середніх показників ЧСС, оскілки максимальний показник в таких іграх є епізодичним так короткотривалим, відповідно не $\epsilon$ небезпечним. Також в залежності від сценарію гри або амплуа гравця, ролі в яких навантаження $\epsilon$ меншим слід давати слабшим гравцям або гравцям 3 послабленим здоров'ям.

Юнацький вік (15-18 років) є періодом закінчення основних процесів дозрівання. Наближується до завершення процес окостеніння, збільшується об'єм м'язової маси, що дозволяє застосовувати в заняттях вправи, ігри та розваги, що вимагають найвищої координації рухів, зростає здібність до витривалості і перенесенню великих за обсягом та інтенсивністю навантажень. Для цього віку характерним є досягнення найвищих темпів розвитку фізичного потенціалу в цілому.

\section{Висновки:}

1. У віці 16-18 років і в наступні роки рухливим іграм відводиться допоміжна роль, а провідна надається спортивним іграм. При тому вправи, ігри і розваги чинять не менший вплив на роботу серця, судин, органів дихання і м'язів, що робить їх вагомим засобом фізичного розвитку. 
2. Розроблена класифікація рухливих ігор за рівнем інтенсивності дозволить більш ефективно застосовувати їх в процесі фізичного виховання студентів. Визначати дозування відповідно до рівня фізичної підготовленості та мети заняття.

\section{Перспективи подальших досліджень:}

1. Продовжити вивчення впливу рухливих ігор на ССС контингенту, що вивчається та скласти класифікацію загальновідомих ігор.

2. Дослідити та експериментально перевірити вплив рухливих ігор на показники фізичної підготовленості.

3. Розробити методичні рекомендації по застосуванню ігор для впливу на рухові якості що потребують корекції.

1. Приступа $Є \mathrm{H}$, Слімаковський О, Лук'янченко М. Українські народні рухливі ігри, розваги та забави: методологія, теорія і практика. Дрогобич: Вимір. 1999.

2. Соломонко АО, Соломонко ВВ, Лисенчук ГА, Соломонко О. Вправи, ігри та розваги у вільний час : методичний посібник. Київ, 2012. 125 с.

3. Максименко СД. Загальна психологія. К.: Форум, 2000.

4. Дьяченко В. Новая дидиктика. М.: Народное образование, 2001. 496 с.

5. Кучер ВО, Григус ІМ. Застосування рухливих ігор та їх вплив на організм школярів. Педагогіка, психологія та медико-біологічні проблеми фізичного виховання і спорту : наук. журн. Х.: ХОВНОКУХДАДМ, 2013; № 1: 39-43.

6. Магльований АВ. Романюк О, Магльована Г. Дозування навантажень занять фізичним вихованням студенток. Молода спортивна наука України. 2015; Т. 2: 160-166

7. Приступа $\mathrm{CH,} \mathrm{Левків} \mathrm{В} \mathrm{І,} \mathrm{Слімаковський} \mathrm{ОВ.} \mathrm{Українські} \mathrm{народні} \mathrm{ігри:} \mathrm{монографія} \mathrm{Л.:} \mathrm{ЛДУФК,} 2012$. $432 \mathrm{c}$.

8. Демчишин АА, Мозола РС. Рухливі ігри. Київ : Радянська школа, 1985. 190 с.

9. Цьось АВ. Фізичне виховання в календарній обрядовості українців: навчальний посібник. Луцьк: Надстир'я, 2000. 376 с.

\section{References}

1. Prystupa YeN, Slimakovskyi O, Lukianchenko M. Ukrainski narodni rukhlyvi ihry, rozvahy ta zabavy: metodolohiia, teoriia i praktyka. Drohobych: Vymir. 1999.

2. Solomonko AO, Solomonko VV, Lysenchuk HA, Solomonko O. Vpravy, ihry ta rozvahy u vilnyi chas : metodychnyi posibnyk. Kyiv, 2012. $125 \mathrm{~s}$.

3. Maksymenko SD. Zahalna psykholohiia. K.: Forum, 2000.

4. Diachenko V. Novaia dydyktyka. M.: Narodnoe obrazovanye, 2001. $496 \mathrm{~s}$.

5. Kucher VO, Hryhus IM. Zastosuvannia rukhlyvykh ihor ta yikh vplyv na orhanizm shkoliariv. Pedahohika, psykholohiia ta medyko-biolohichni problemy fizychnoho vykhovannia i sportu : nauk. zhurn. Kh.: KhOVNOKU-KhDADM, 2013; № 1: 39-43.

6. Mahlovanyi AV. Romaniuk O, Mahlovana H. Dozuvannia navantazhen zaniat fizychnym vykhovanniam studentok. Moloda sportyvna nauka Ukrainy. 2015; T. 2: 160-166

7. Prystupa YeN, Levkiv V I, Slimakovskyi OV. Ukrainski narodni ihry: monohrafiia L. : LDUFK, 2012. $432 \mathrm{~s}$.

8. Demchyshyn AA, Mozola RS. Rukhlyvi ihry. Kyiv : Radianska shkola, 1985. $190 \mathrm{~s}$.

9. Tsos AB. Fizychne vykhovannia $\mathrm{v}$ kalendarnii obriadovosti ukraintsiv: navchalnyi posibnyk. Lutsk: Nadstyria, 2000. $376 \mathrm{~s}$.

\section{Цитування на цю статтю:}

Соломонко АO, Андрес АС. Систематизація рухливих ігор та розваг для студентів 15-17 років згідно їх пульсової вартості. Вісник Прикарпатського університету. Серія: Фізична культура. 2019 Берез 26; 33 : $89-96$

\begin{tabular}{|c|c|}
\hline Відомості про автора: & Information about the author: \\
\hline $\begin{array}{l}\text { Соломонко Андрій Олександрович - аспірант, } \\
\text { Львівський державний університет фізичної куль- } \\
\text { тури імені Івана Боберського (Львів, Україна) }\end{array}$ & $\begin{array}{l}\text { Solomonko Andrii Oleksandrovych - post-graduate } \\
\text { student, Lviv State University of Physical Culture } \\
\text { (Lviv, Ukraina) }\end{array}$ \\
\hline $\begin{array}{l}\text { e-mail: oknomolosa@ gmail.com } \\
\text { https://orcid.org/0000-0003-1631-9254 }\end{array}$ & \\
\hline
\end{tabular}




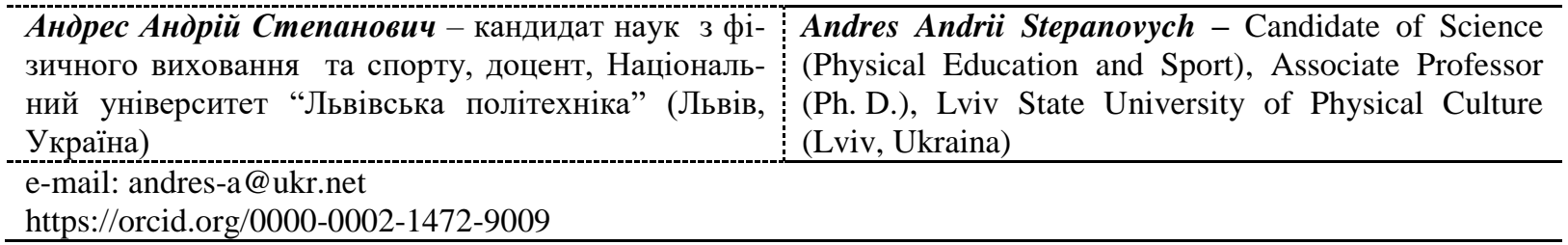

УДК 796.332+ 796.012.1 doi: 10.15330/fcult.33.96-102

Ганна Тітова, Володимир Бобошко, Сергій Можин

\title{
СПОРТИВНИЙ ВІДБІР НА ПОЧАТКОВИХ ЕТАПАХ ПІДГОТОВКИ ЮНИХ ФУТБОЛІСТІВ
}

\begin{abstract}
Конституція людини, щุо проявляється, зокрема, в особливостях статури, залежить як від спадкових чинників, так і від чинників зовнішнього середовища: соиіальних умов, живлення, перенесених хвороб, умов прачі, занять фізичними вправами і спортом.

Характерною особливістю сучасного спорту є науково обтрунтований пошук талановитих дітей $i$ молодих людей, яким до снаги великі тренувальні та змагальні навантаження $i$ найвищі темпи спортивного вдосконалення. При максимальній інтенсифікації навантажень, відчайдушній боротьбі рівних за силами суперників, сильних емочійних переживаннях, напруженій діяльності всіх систем організму тільки кращі з найкращчих можуть досягнути вагомих результатів у спорті.

Природний відбір не дозволяє вирішити проблему підготовки кваліфікованого резерву, оскільки, згідно статистичних даних, відомо, щзо в ДЮСШ, СДЮШОР, УФК, УОР, спеціалізованих класах $з$ футболу відбувається значне “відсіювання” дітей, які займаються футболом. Близько 70\% юних футболістів припиняють заняття через невідповідність програм відбору $і$ підготовки кваліфікованих виконавиів.
\end{abstract}

Ключові слова: спортивний відбір, футбол, початковий етап тренування.

The constitution of man, manifested, in particular, in the peculiarities of physique, depends both on hereditary factors and on factors of the external environment: social conditions, nutrition, illnesses, conditions of work, physical activity and sports.

A characteristic feature of contemporary sports is the scientifically based search for talented children and young people who have great training and adventure loads and the highest pace of sport improvement. With the maximum intensification of loads, the desperate struggle of equal forces of rivals, strong emotional experiences, intense activity of all systems of the body, only the best of the best can achieve weighty results in sports.

Natural selection does not allow to solve the problem of qualified reserve preparation, since, according to statistical data, it is known that in specialized schools of football there is a significant "sifting" of children involved with football. About $70 \%$ of young footballers stop their classes due to inconsistencies in selection and training programs for skilled performers.

The method of sports selection at the stage of initial training is determined by the main task of the first selection meeting - helping the child to choose the right sport for further sport improvement. The correct solution to this problem shows not only the effectiveness of the work of children's and youth sports schools, individual trainers or organizers of football, but also has a great social significance.

Already with the first assessment of the promise of children it is necessary to rely on the qualities and abilities that determine the success of a qualified sport. First of all, one must be guided by stable, very variables in the development of factors. These requirements correspond to the morphological features.

It is from measurements of total body size, in combination with a visual assessment of the appearance of the child to begin determining its promise.

It should be emphasized that the indicators of physical fitness for initial selection are inadequate, since they are more dependent on training effects. Indicators of mental and mental performance of children are poorly studied, however, it seems that these indicators can be very informative for trainers or specialists who conduct the primary sport selection in football.

Key words: sports selection, football, initial stage of training. 